\title{
Rare occurrence of nine Microcystis species (Chroococcales, Cyanobacteria) in a single lake (Lake Dojran, fYR Macedonia)
}

\author{
Svetislav Krstić, ${ }^{1 *}$ Boris Aleksovski, ${ }^{1}$ Jiří Komárek ${ }^{2}$
}

${ }^{1}$ Faculty of Natural Sciences and Mathematics, "Ss. Cyril and Methodius" University, Arhimedova 3, P.O. Box 162, 1000 Skopje, fYR Macedonia; ${ }^{2}$ Institute of Botany, Czech Academy of Sciences, Dukelská 135, CZ-37982 Třeboň, Czech Republic

*Corresponding author: skrstic@pmf.ukim.mk

\begin{abstract}
Investigations carried out on Lake Dojran, fYR Macedonia, during the spring-autumn seasons in 2015 have been focused on detecting the degree of eutrophication in the lake, successive algal flora changes in the plankton communities and eventual presence of cyanotoxins (free microcystins) in the water. The obtained results revealed a co-existence of nine Microcystis species in the lake (M. aeruginosa, M. botrys, M. flos-aquae, M. ichthyoblabe, M. novacekii, M. protocystis, M. smithii, M. viridis and M. wesenbergii), with domination of the pan and neo-tropical species M. protocystis, again confirmed in a European lake. Results also corroborate the necessity to change the accepted morphospecies concept into separation of Microcystis taxa as distinct species which are clearly delimited according to their constant morphological features. Toxicity analyses demand for a specific and targeted investigation, since the toxin production and presence depends on many factors, and the toxin dynamics including the highest peaks may be easily overlooked if other issues are in the focus of the performed monitoring. Detected values for free microcystins in the water reached $2.84 \mu \mathrm{g} \mathrm{L}^{-1}$ microcystin-LR equivalents.
\end{abstract}

Key words: Lake Dojran; nine Microcystis species; morphospecies vs species concept.

Received: 18 August 2016. Accepted: 9 December 2016.

\section{INTRODUCTION}

Dojran Lake is situated on the border between two countries, fYR Macedonia and Greece; $2 / 3$ of the open lake waters belonging to the former while the same amount of the catchment area belongs to the later country (Fig. 1). It is considered as a remnant of a much larger tectonic/volcanic Peonic Lake (Plio-Pleistocene) (Stojanov and Micevski, 1989).

Located at $144 \mathrm{~m}$ asl, Dojran Lake has been labeled as a stable eutrophic lake (Stojanovski et al., 1996) with intensive primary production (up to $760 \mathrm{~g} \mathrm{~m}^{-2}$ as periphytic growth on Phragmites spp.; Stojanov, 1986), rich with various microflora and a high fish productivity - the richest lake with fish in south-east Europe. Nevertheless, due to irrigation purposes the lake has been subjected to an intensive water outlet through deepening of the former channel in Greece (Griffiths et al., 2002; Zacharias et al., 2002) what has produced a huge oscillation and decrease in water level which has culminated in 1993, with a total water column decrease of $7 \mathrm{~m}$. This situation has forced an accelerated eutrophication process in this small and quite shallow lake that has been recorded in the chemical, biological and stable isotope records of the surface sediments (Franke et al., 2013).

While the rapid decrease of water level due to abstraction combined with a period of prolonged dry conditions
(1988-1998) has devastated the lake ecosystem, the anthropogenic pressure has also intensified in form of ever increasing waste water input and agricultural diffuse pollution. Consequently, the ecological status of the lake has turned rapidly towards hypertrophy, clearly reflected and documented in its microflora communities (Stojanovski et al., 1997). Namely, at the first instance in period 19881990 the hitherto scarce populations of the periphytic Gloeotrichia natans Rabenhorst ex Bornet \& Flahault have exploded into mass domination in periphytic and planktic (in their later stages) communities with extensive biomass. This event has caused a rapid depletion of oxygen in the whole water column and a mass extinction of the bottom dwelling mollusks [Dreissena presbensis (D.polymorpha)], but also a massive succession in microflora assemblages towards domination of Asterionella gracillima (Hantzsch) Heiberg, Dolichospermum flosaquae (Brébisson ex Bornet \& Flahault) P.Wacklin, L.Hoffmann \& J.Komárek and Dolichospermum sigmoideum (Nygaard) Wacklin, L.Hoffmann \& Komárek (Stojanovski et al., 1997). Many of detected taxa belonging to blue-green algae (like Chroococcus minutus (Kützing) Nägeli, Merismopedia glauca (Ehrenberg) Kützing, M. punctata Meyen and many others) and green algae (like various Pediastrum, Scenedesmus, Ankistrodesmus, Golenkinia, Tetraedron, Crucigenia, or desmid taxa) have disappeared from the system, while the diatom community has evidently shifted towards taxa composition in-

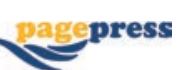


dicative for higher levels of trophy and salinity. Many of the persistent and alarming scientific publications and public information (Stojanovski et al., 1997) or propositions for helping the Dojran Lake and minimizing the lethal effects of the forced ecocide (Stojanovski et al., 1995; Krstić et al., 1996) have been in vain.

For a long time, the lake Dojran has been left without any monitoring system in place and with a very doubtful attempt to bring additional water supply originating from River Vardar by means of artificial system of channels. As a result, the water level rose at $2.5 \mathrm{~m}$ below the optimum while the ecological parameters of the water got worse due to heavy impact of the River Vardar's highly polluted waters. The deep layer of organic mud, at places reaching to $7 \mathrm{~m}$ in depth, and the continuous input of untreated waste waters have resulted in dominating cyanobacterial blooms consisted of Microcystis aeruginosa (Kützing) Kützing, Microcystis ichthyoblabe (G.Kunze) Kützing, Microcystis wesenbergii (Komárek) Komárek ex Komárek and Planktolyngbya contorta (Lemmermann) Anagnostidis \& Komárek, with some remnants the previous microflora like Aphanizomenon flos-aquae Ralfs ex Bornet \& Flahault, Dolichospermum scheremetieviae (Elenkin) Wacklin, L.Hoffmann \& Komárek, Aphanocapsa elachista West \& G.S.West or Pediastrum boryanum (Turpin) Meneghini still present in very limited numbers (Krstić, 2011). At this point the dominant cyanobacterial community has produced the highest hitherto detected dissolved microcystins concentration in a grab water sample for fYR Macedonia detected by ELISA - $270 \mu \mathrm{g} \mathrm{L}^{-1}$ microcystin-LR equivalents.

Therefore, during 2015, we aimed to investigate the intensity of the eutrophication processes and the present microalgal communities in Dojran Lake, with a special focus on the taxonomically important genus Microcystis and the morphological characters of the detected Microcystis species. The results of the determined cyanobacterial community structure, plankton species composition and successions in relation to water quality parameters, as well as the detected free microcystins concentrations in the water are presented in this study.

\section{METHODS}

Filed sampling campaigns were conducted on $6^{\text {th }}$ of May, $5^{\text {th }}$ of July and $28^{\text {th }}$ of September 2015, on three sampling sites (Fig. 1): two near shore locations in vicinity of the major settlements and one pelagic open water site near the border with Greece.

Field measurements included basic physicochemical parameters (temperature, $\mathrm{pH}$, dissolved oxygen, oxygen saturation, conductivity) by means of portable equipment Senso Direct 150 multimeter, while the measurements of basic nutrients and chlorophyll $a$ were performed according to laboratory protocol standard methods (APHA, 1998)
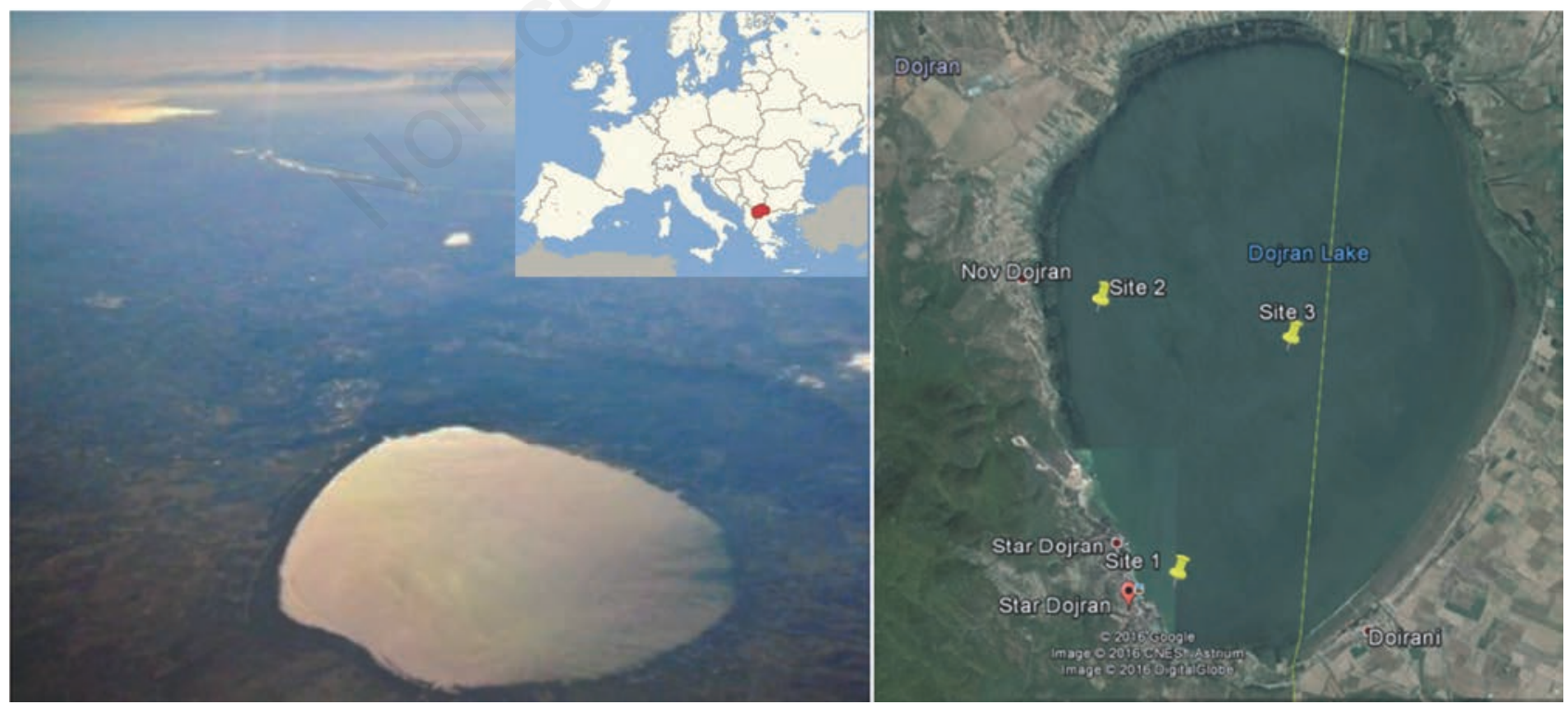

Fig. 1. Aerial photograph of Dojran Lake $\left(41^{\circ} 12^{\prime} \mathrm{N}, 22^{\circ} 44^{\prime} \mathrm{E}\right)$. The lake water mirror, final part of River Vardar prior to confluence in Thessaloniki bay and the bay itself are visible. Locations of the sampling sites on Lake Dojran (43.1 km², max. depth $8 \mathrm{~m}$, N-S length

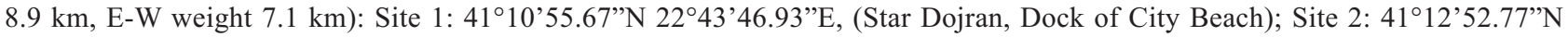

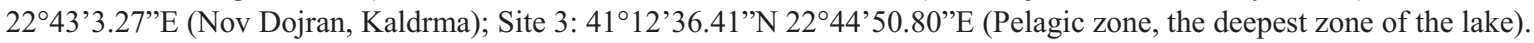


using spectrophotometer Lovibond Tintometer $\AA$. The measurement of the basic physicochemical parameters, nutrients and chlorophyll $a$ was performed on an integrated water sample using Ruttner water sampler. For the measurement of dissolved nutrients, the water sample was firstly filtrated through $0.45 \mu \mathrm{m}$ membrane filters. The maximal depth was measured with weighted marked line.

The plankton material was collected by means of a planktic net (pore size $10 \mu \mathrm{m}$ ) by slowly dragging using a motor boat, or by means of vertical column mixing. Collected material was preserved in $4 \%$ formaldehyde or in Lugol's solution for further processing in the laboratory (WHO, 1999). All plankton material was analyzed by standard light microscopy, but for better visualization of the mucilaginous envelope, the material was also stained with China Ink and analyzed in details. Microphotographs were taken both from native materials and stained colonies with Nikon eclipse E800M LM with Nikon Coolpix 4500 camera. The identification of the species was performed using standard literature (Komárek and Anagnostidis, 1998; Šejnohová and Maršálek, 2012) as well as the main report for European Microcystis morphospecies (Komárek and Komárková, 2002).

For the first and second campaign we have also performed toxin analyses. For this purpose, $50 \mathrm{~mL}$ of the integrated water sample were filtered in situ through glass-fiber filters $47 \mathrm{~mm}(\mathrm{GF} / \mathrm{C})$ using vacuum filtration device. The filtrated samples were transported on cold and kept frozen at $-20^{\circ} \mathrm{C}$ till the day of the analysis. The quantitative detection of free microcystins in the samples was performed using the Microcystins-ADDA ELISA kit from Abraxis (Product No. 520011) according to the manufacturer's instructions. All analyses were performed in triplicate. The assay was calibrated with microcystin-LR and the results were expressed as microcystin-LR equivalents.

\section{RESULTS}

\section{Basic physicochemical parameters}

The results obtained from the basic physicochemical analyses of the lake's water as well as the principal nutrients are presented on Tab. 1. These results clearly reflect the seasonal changes in the water chemistry and they also point out several important trends:

- The water temperature was almost constant in the whole period indicating the shallowness of the lake and the intensity of the mixing of water column, but also the favorable conditions for an intensive cyanobacteria development throughout the investigated period;

- As expected, the measurements for dissolved oxygen and $\mathrm{pH}$ showed an opposite trend, oxygen a tendency of depletion towards the summer months while the $\mathrm{pH}$ a trend of increasing towards increased alkalinity. The conductivity also had an increasing trend towards autumn;

- All of the measured nutrients showed marked increase of their concentrations towards the autumn, the total $\mathrm{N}$ being the most pronounced one, but total $\mathrm{P}$ had also very obvious increase towards summer and autumn period. These findings directly corroborate the intensive tourist pressure on the lake during summer and lack of any waste water treatment activities (also presented in the detected nitrite values);

- Chlorophyll $a$ concentrations revealed two distinct peaks, one in July when the increased algal concentration was recorded in a near shore location (site 1) and the second one in September which was almost double in value, but during this month the intensive presence of significant algal biomass was recorded in all three sampling stations.

It seems that the pollution pressure was intensive, con-

Tab. 1. Basic physicochemical parameters of the Dojran Lake water in all three seasons and sampling sites.

\begin{tabular}{|c|c|c|c|c|c|c|c|c|c|}
\hline & \multicolumn{3}{|c|}{$1^{\text {st }}$ sampling (May) } & \multicolumn{3}{|c|}{$2^{\text {nd }}$ sampling (July) } & \multicolumn{3}{|c|}{$3^{\text {rd }}$ sampling (September) } \\
\hline & Site 1 & Site 2 & Site 3 & Site 1 & Site 2 & Site 3 & Site 1 & Site 2 & Site 3 \\
\hline Maximal depth (m) & 4 & 5.5 & 8 & 5 & 4.8 & 8 & 5 & 4 & 8 \\
\hline Temperature $\left({ }^{\circ} \mathrm{C}\right)$ & 22.6 & 24.7 & 22.9 & 24 & 25 & 24 & 23.4 & 25.6 & 23.5 \\
\hline D.O. $\left(\mathrm{mg} \mathrm{L}^{-1}\right)$ & 9.4 & 9.2 & 9.2 & 4.5 & 2.5 & 5.7 & 10.7 & 6.1 & 8.1 \\
\hline $\mathrm{pH}$ & 7.64 & 7.88 & 8.04 & 8.23 & 8.60 & 9.27 & 9.39 & 8.78 & 8.86 \\
\hline Conductivity $(\mu \mathrm{S})$ & 582 & 646 & 638 & 750 & 722 & 686 & 705 & 725 & 735 \\
\hline Secchi depth (m) & 4 & 4 & 4 & 3 & 2.2 & 2.7 & 1.2 & 0.9 & 1.2 \\
\hline Chl a $\left(\mu \mathrm{g} \mathrm{L}^{-1}\right)$ & 2 & 0.9 & 0.332 & 11.88 & 3.88 & 4.26 & 13.4 & 22.7 & 17.1 \\
\hline Total $\mathrm{P}\left(\mu \mathrm{g} \mathrm{L}^{-1}\right)$ & 90 & 150 & 170 & 120 & 210 & 200 & 280 & 380 & 150 \\
\hline Total N $\left(\mu \mathrm{g} \mathrm{L}^{-1}\right)$ & 600 & 1900 & 800 & 600 & 6400 & 1100 & 980 & 730 & 1320 \\
\hline Ammonia $\left(\mu \mathrm{g} \mathrm{L}^{-1}\right)$ & 50 & 20 & 20 & 60 & $<20$ & $<20$ & 140 & 180 & 50 \\
\hline Nitrite $\left(\mu \mathrm{g} \mathrm{L} \mathrm{L}^{-1}\right)$ & $<10$ & 12 & $<10$ & $<10$ & $<10$ & $<10$ & 19 & 36 & $<10$ \\
\hline Nitrate $\left(\mathrm{mg} \mathrm{L}^{-1}\right)$ & $<1$ & $<1$ & $<1$ & $<1$ & $<1$ & $<1$ & 2.5 & 1.5 & $<1$ \\
\hline Potassium $\left(\mathrm{mg} \mathrm{L}^{-1}\right)$ & 7.5 & 9.5 & 8.8 & 9.5 & 7.0 & 7.2 & 11 & 8.9 & 6 \\
\hline
\end{tabular}


stant and prolonged during the investigated period (Tab. 1), with a clear increase of the observed parameters over the summer-autumn period. This ecological situation should have been reflected in the plankton communities and algal flora successions what has been documented in this study.

\section{Dynamics of plankton communities and Microcystis spp. dominance}

Our results concerning the planktic communities for the first sampling in May are shown in Fig. 2. On the first site, a domination of the zooplankton was recorded. The phyto- plankton was composed of Microcystis species in association with Melosira varians C.Agardh. We did not detect any green algae. Six Microcystis species were determined, with co-dominance of $M$. protocystis Crow and M. aeruginosa. Site 2 showed almost complete domination of the zooplankton $(90.6 \%)$. In the phytoplankton, high domination of Sphaerocystis sp. (probably S. schroeteri) was detected and low abundance of the genus Microcystis. Two Microcystis species were identified: $M$. aeruginosa and M. flos-aquae (Wittrock) Kirchner. However, we have detected domination of the phytoplankton in Site 3, with massive presence of Sphaerocystis sp. and low abundance of the genus Microcystis. Six Microcystis species were identified: $M$.
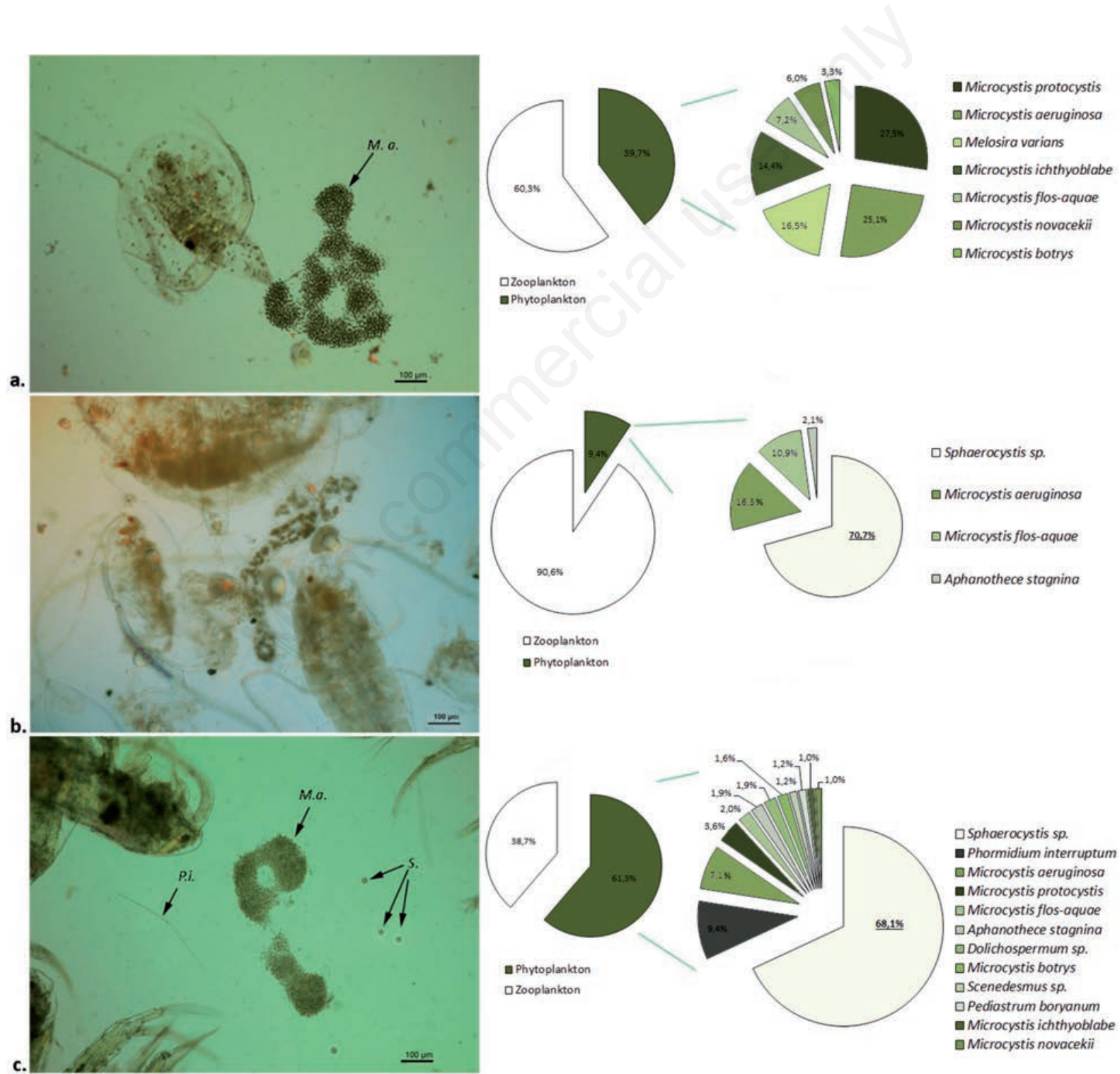

口Zooplankton

aPhytoplankton

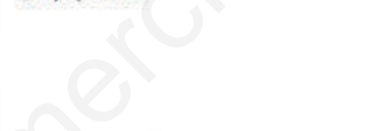

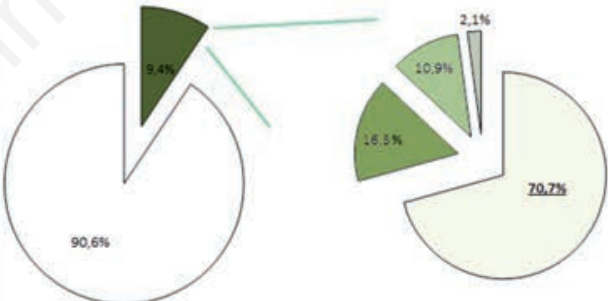

QZooplankton

v Phytoplankton

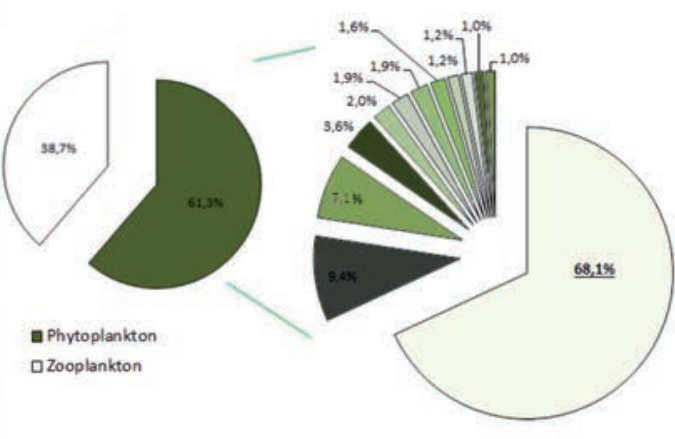

$\square$ Sphaerocystis sp.

- Microcystis aeruginoso

Microcystis flos-aquae

$\square$ Aphanothece stagnina

$\square$ Sphaerocystis sp

- Phormidium interruptum

Microcystis aeruginosa

Microcystis protocystis

$\square$ Microcystis flos-aquae

$\square$ Aphanothece stagnina

Dolichospermum sp.

Microcystis botrys

口Scenedesmus sp.

Pediastrum boryanum

Microcystis ichthyoblabe

Microcystis novacekii

Fig. 2. First sampling campaign conducted in May, 2015. a) Site 1. b) Site 2. c) Site 3. M.a., Microcystis aeruginosa; P.i., Phormidium interruptum; S., Sphaerocystis sp. 
aeruginosa, M. protocystis, M. flos-aquae, M. botrys Teiling, M. ichthyoblabe and M. novacekii (Komárek) Compère in association with Phormidium interruptum Kützing ex Forti, Aphanothece stagnina A. Braun and low presence of Pediastrum boryanum and Scenedesmus sp.

Our results from the second sampling in July are shown on Fig. 3. On Site 1 we have detected domination of the phytoplankton with co-dominance of Aphanizomenon gracile Lemmermann, M. protocystis and M. ichthyoblabe. Six Microcystis species were present on this site from which $M$. aeruginosa, $M$. botrys, $M$. novacekii and $M$. smithii Komárek \& Anagnostidis were present with low abundance in association with colonies of Volvox aureus Ehrenberg. Presence of the endogloeic Pseudanabaena mucicola (Naumann \& Huber-Pestalozzi) Schwabe was detected in the mucilage of Microcystis spp. The second site (Site 2) was characterized by massive domination of the phytoplankton (completely opposite from the first sampling in May), with M. ichthyoblabe as clearly dominant species, with fully developed, and sometimes macroscopic (gigantic) colonies. $M$. protocystis was also well developed and the rest two Microcystis species (M. aeruginosa and

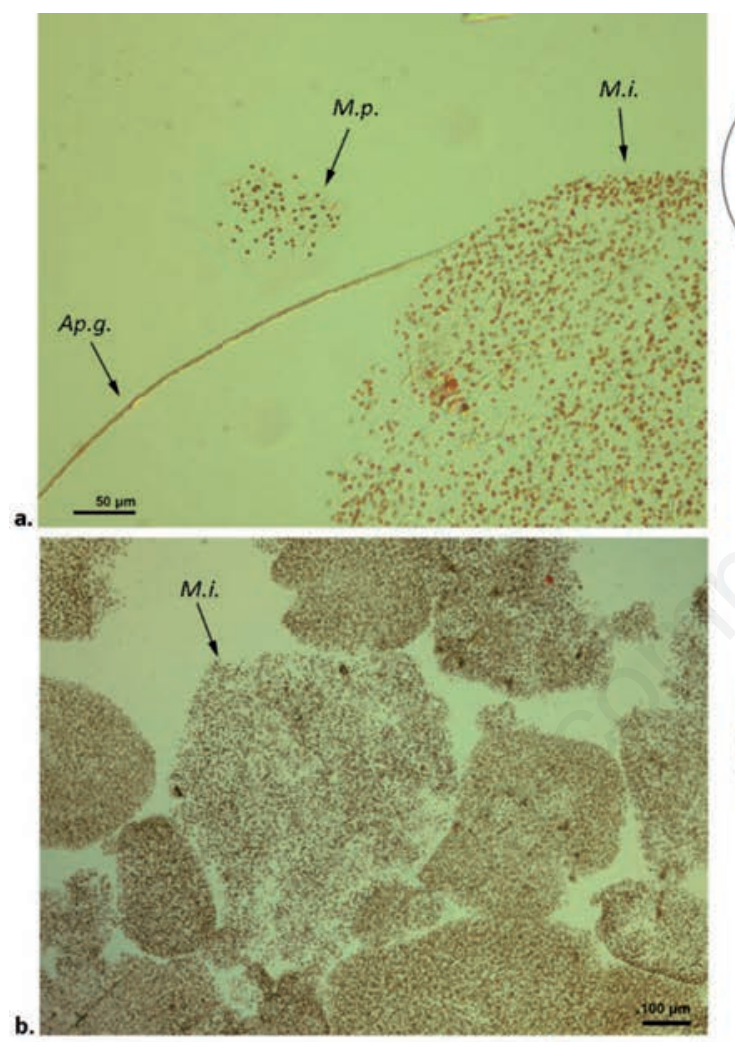

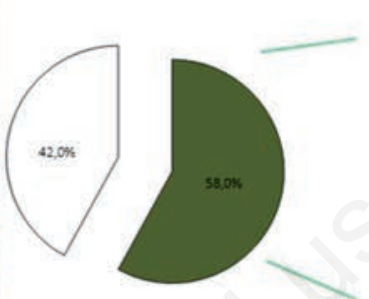

口Zooplankton a Phytoplankton

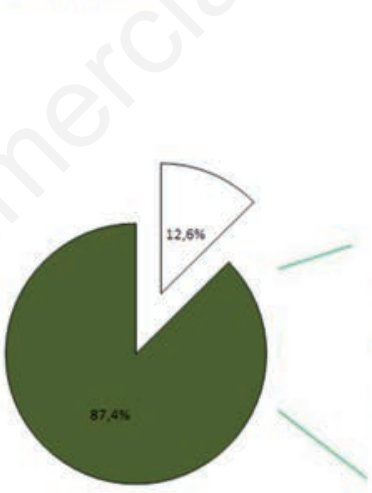

口Zooplankton

a Phytoplankton
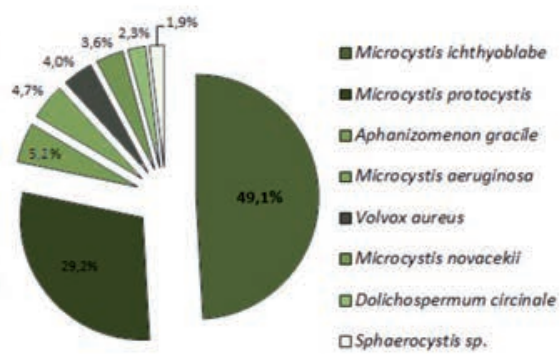

口Sphoerocystis sp.
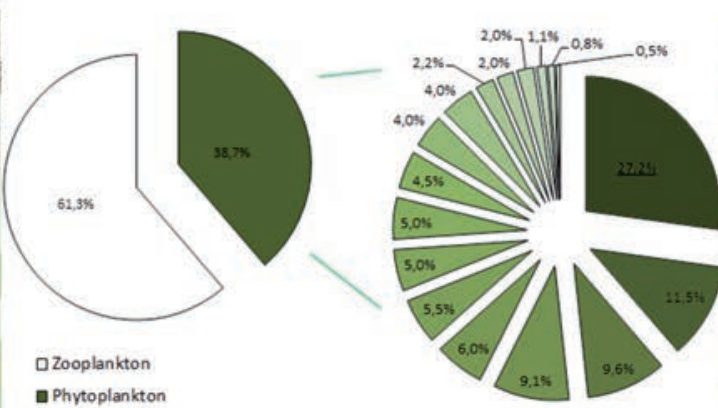

Microcystis protocystis Microcystis ichthyoblabe - Gloeothece membranace a Microcystis novacekil A Aphanizomenon gracile Microcystis aeruginosa a Phormidium sp. Planktolyng bya contorto Microcystis botrys a Dolichospermum circinale 口Eudorina sp. Microcystis flos-aquae 口Aphanocapsa sp. $\square$ Sphaerocystis sp. Microcystis wesenbergil 口Microcystis viridis 口 Pediastrum boryanum

Fig. 3. Second sampling campaign conducted in July, 2015. a) Site 1. b) Site 2. c) Site 3. M.p., Microcystis protocystis; Ap.g., Aphanizomenon gracile; M.i., Microcystis ichthyoblabe; D., Dreissena sp. larvae; M.n., Microcystis novacekii. 
M. novacekii) were poorly present. Microcystis species were detected in association with Aphanizomenon gracile and Volvox aureus. Our results have also shown high presence of the endogloeic Pseudanabaena mucicola in the mucilage of the Microcystis spp. However, on the third site (Site 3), we have determined clear domination of the zooplankton $(61.3 \%)$, because of the massive presence of the Dreissena sp. larvae. The phytoplankton was not dominant, but nevertheless quite rich with cyanobacterial taxa. Eight Microcystis species were identified. M. protocystis showed dominance, with Microcystis ichthyoblabe as subdominant. The rest Microcystis spp. (M. novacekii, M. aeruginosa, M. botrys, $M$. flos-aquae, $M$. wesenbergii and M. viridis (A. Braun) Lemmermann) were not abundant. The detected Microcystis species were identified in coin- cidence with several other cyanobacteria: Gloeothece membranacea (Rabenhorst) Bornet, Aphanizomenon gracile, Phormidium sp., Planktolyngbya contorta and Dolichospermum circinale (Rabenhorst ex Bornet \& Flahault) P. Wacklin, L. Hoffmann \& J. Komárek. The high presence of the endogloeic Pseudanabaena mucicola was again confirmed.

The results from the third sampling in September are presented in Fig. 4. On the first site the phytoplankton was dominant, with clear dominance of Aulacoseira granulata (Ehrenberg) Simonsen in association with massive presence of Microcystis colonies. All nine species of the genus Microcystis were present, with high abundance of $M$. protocystis and $M$. aeruginosa (always with big and well developed colonies). The rest Microcystis spp. (M.novacekii, a.

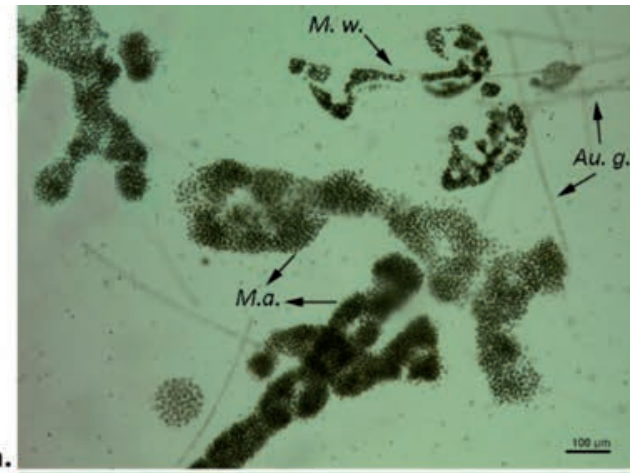

b.

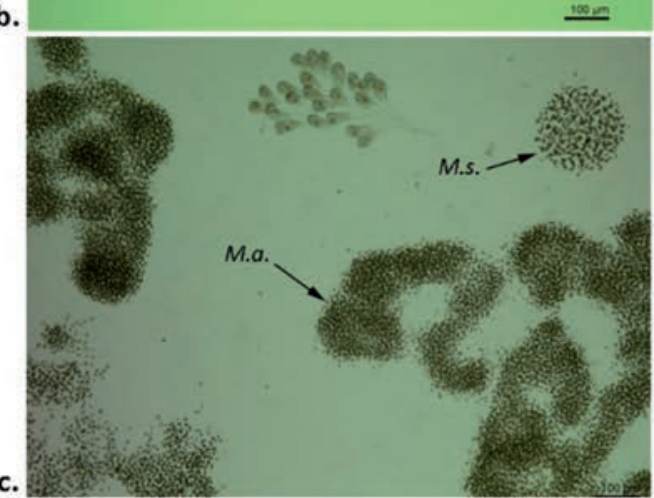
$\underline{100010}$

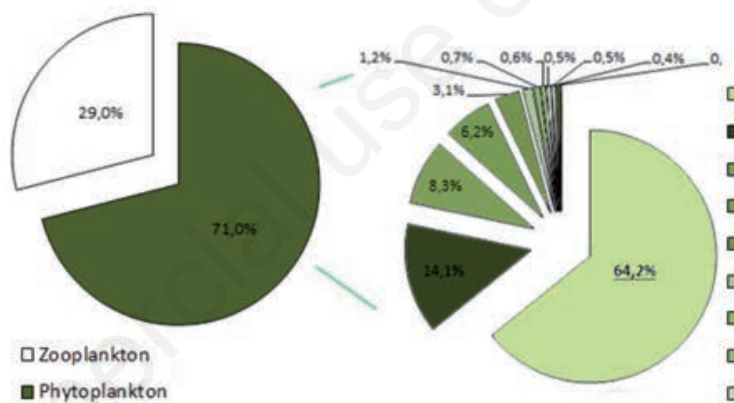

a Phytoplankton

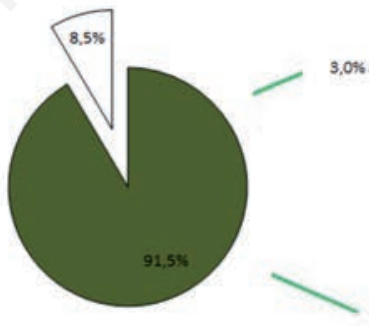

a Phytoplankton 口Zooplankton
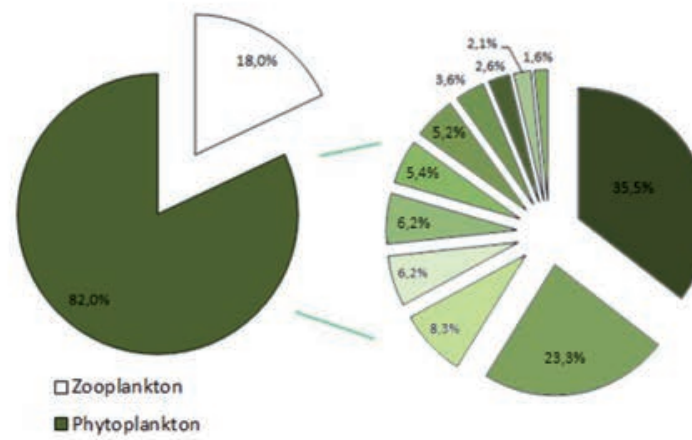

- Microcystis protocystis 口Microcystis aeruginosa $\square$ Aulacoseira granulata 口Microcystis smithil 口Dolichospermum circinale 口Microcystis botrys 口Aphanizomenon gracile aMicrocystis novacekil

- Microcystis ichthyoblabe Microcystis flos-aquae 口Planktolyngbya contorto

Fig. 4. Third sampling campaign conducted in September, 2015. a) Site 1. b) Site 2. c) Site 3. Au.g., Aulacoseira granulata; M.w., Microcystis wesenbergii; M.a., Microcystis aeruginosa; M.p., Microcystis protocystis; M.s., Microcystis smithii. 
M. flos-aquae, M. botrys, M. wesenbergii, M. smithii, $M$. ichthyoblabe and $M$. viridis) showed low abundance. The Microcystis spp. were found in coincidence with Aphanizomenon gracile and Dolichospermum circinale. The second site was characterized by complete domination of the phytoplankton, in which $M$. protocystis showed clear dominance, with $M$. ichthyoblabe as a subdominant species. Six Microcystis spp. were present, from which M. novacekii, $M$. aeruginosa, $M$. wesenbergii and $M$. smithii were poorly present. Green algae and the diatom Aulacoseira granulata were not detected on this site. Site 3 showed domination of the phytoplankton, with massive presence of Microcystis colonies. Seven species of the genus Microcystis were present, with massive domination of $M$. protocystis and big and well developed colonies of $M$. aeruginosa. The rest of the Microcystis species were not present in high abundance $(M$. smithii, $M$. botrys, $M$. novacekii, $M$. ichthyoblabe and $M$. flos-aquae). The colonies of Microcystis were in clear association with Aulacoseira granulata, as well as with Dolichospermum circinale and Aphanizomenon gracile. High presence of the endogloeic Pseudanabaena mucicola in the mucilage of the Microcystis colonies was also detected in all three sites in this campus.

In all, the obtained results from this investigation showed a distinctive pattern of plankton dynamics over the sampling period. Namely, spring samplings revealed the dominance of zooplankton over phytoplankton in near shore locations, while the pelagic waters have clear dominance of phytoplankton taxa with limited presence of six Microcystis taxa (M. aeruginosa, M. botrys, M. flosaquae, M. ichthyoblabe, M. novacekii and M. protocystis). Plankton communities collected in the second sampling campaign in July 2015 had a completely different structure than in May. If the dominance of Dreissena sp. larvae in pelagic zone is excluded (due to the period of reproduction of mussels), the plankton was fully dominated by phytoplankton communities, clearly consisted of eight
Microcystis taxa (M. aeruginosa, M. botrys, M. flosaquae, $M$. ichthyoblabe, $M$. novacekii, $M$. protocystis, $M$. viridis and $M$. wesenbergii) where $M$. ichthyoblabe and $M$. protocystis took the dominant role, with significantly declined abundance of Sphaerocystis sp. Finally, in September 2015, M. protocystis and the well-developed colonies of $M$. aeruginosa have characterized the plankton community, with frequent observations of long Aulacoseira granulata chains (replacing the previously detected Melosira varians). All nine Microcystis taxa ( $M$. aeruginosa, $M$. botrys, M. flos-aquae, M. ichthyoblabe, $M$. novacekii, $M$. protocystis, $M$. smithii, $M$. viridis and $M$. wesenbergii) were detected in the same time.

\section{Toxin analyses}

The levels of free microcystins (expressed as microcystin-LR equivalents) as well as the relations between the concentration of free microcystins and the domination of species are shown on Tab. 2 .

\section{DISCUSSION}

According to Komárek \& Komárková (2002) and Šejnohová \& Maršálek (2012), the species concept within cyanobacteria, and especially Microcystis, is still problematic and doubtful. The wide variations in the basic differential characteristics among species, like form of the colony, mucilage structure, cell diameter, the organization and structure of cells within the colony, pigment content and life cycles have resulted in application of the taxonomic term 'morphospecies' which expresses significant overlap of the limiting criteria (Cronberg \& Komárek, 1994). Consequently, the numerous unidentifiable colonies, atypical stages or transient forms of Microcystis have resulted in a proposition that all main morphospecies (M. aeruginosa, M. ichthyoblabe, M. viridis, M. no-

Tab. 2. Detected values for dissolved microcystin-LR presence in Dojran Lake sites for the two sampling campaigns in 2015.

\begin{tabular}{|c|c|c|c|}
\hline & & $\begin{array}{l}\text { centration, } \\
\text { LR equiv. } \\
\left.\mu \mathrm{g} \mathrm{L}^{-1}\right)\end{array}$ & Domination of species \\
\hline \multirow{3}{*}{$1^{\text {st }}$ sampling (May) } & Site 1 & 2.8 & $\begin{array}{l}\text { Domination of zooplankton; in the frame of the phytoplankton co-dominance of } M \text {. protocystis and } \\
\text { M. aeruginosa }\end{array}$ \\
\hline & Site 2 & 1.5 & Domination of zooplankton and Sphaerocystis, low \% of Microcystis spp. \\
\hline & Site 3 & 0.5 & Domination of Sphaerocystis sp., low abundance of Microcystis spp. \\
\hline \multirow[b]{3}{*}{$2^{\text {nd }}$ sampling (July) } & Site 1 & 1.3 & $\begin{array}{l}\text { Co-domination of Aphanizomenon gracile, M. protocystis and M. ichthyoblabe. Presence of the } \\
\text { endogloeic Pseudanabaena mucicola }\end{array}$ \\
\hline & Site 2 & 0.6 & $\begin{array}{l}\text { Clear domination of } M \text {. ichthyoblabe, } M \text {. protocystis is subdominant. All the rest are poorly present. } \\
\text { High presence of the endogloeic Pseudanabaena mucicola }\end{array}$ \\
\hline & Site 3 & 1.5 & $\begin{array}{l}\text { Domination of the zooplankton (because of the massive presence of the Dreissena sp. larvae), but quite } \\
\text { rich with Microcystis spp. M. protocystis shows dominance and } M \text {. ichthyoblabe is subdominant } \\
\text { High presence of the endogloeic Pseudanabaena mucicola }\end{array}$ \\
\hline
\end{tabular}


vacekii, $M$. wesenbergii) should be taxonomically unified (Otsuka et al., 2001) under the Bacteriological Code of nomenclature. Additionally, according to the results provided by molecular sequencing, a lot of Microcystis species were found genetically similar, so the question if all of them should be considered as one species was raised. Nevertheless, Šejnohová and Maršálek (2012) point out that studies using molecular and biochemical criteria have been proven contradictory and should be used with caution.Having obtained the presented results on Microcystis spp. presence and dominance in Lake Dojran, we believe that new insights can be highlighted on this controversial subject - morphospecies vs species within this cyanobacterial genus. Namely, during the in- vestigated period we have detected fine and gradual succession of Microcystis taxa in this relatively small ecosystem. In general, $M$. protocystis (Plate 6) and $M$. aeruginosa (Plate 1) have dominated in spring and autumn, while in summer M. ichthyoblabe (Plate 4) has taken the sub-dominant position, mostly well developed in the site with the highest recorded waste water pressure (Site 2, Fig. 4). In spring, a total of six Microcystis taxa were recorded (M. aeruginosa, M. botrys, M. flos-aquae, $M$. ichthyoblabe, M. novacekii, $M$. protocystis), while in summer period all nine taxa were present in the lake $(M$. aeruginosa, M. botrys, $M$. flos-aquae, M. ichthyoblabe, M. novacekii, $M$. protocystis, $M$. smithii, $M$. viridis and $M$. wesenbergii). First appearance of $M$. viridis and $M$.

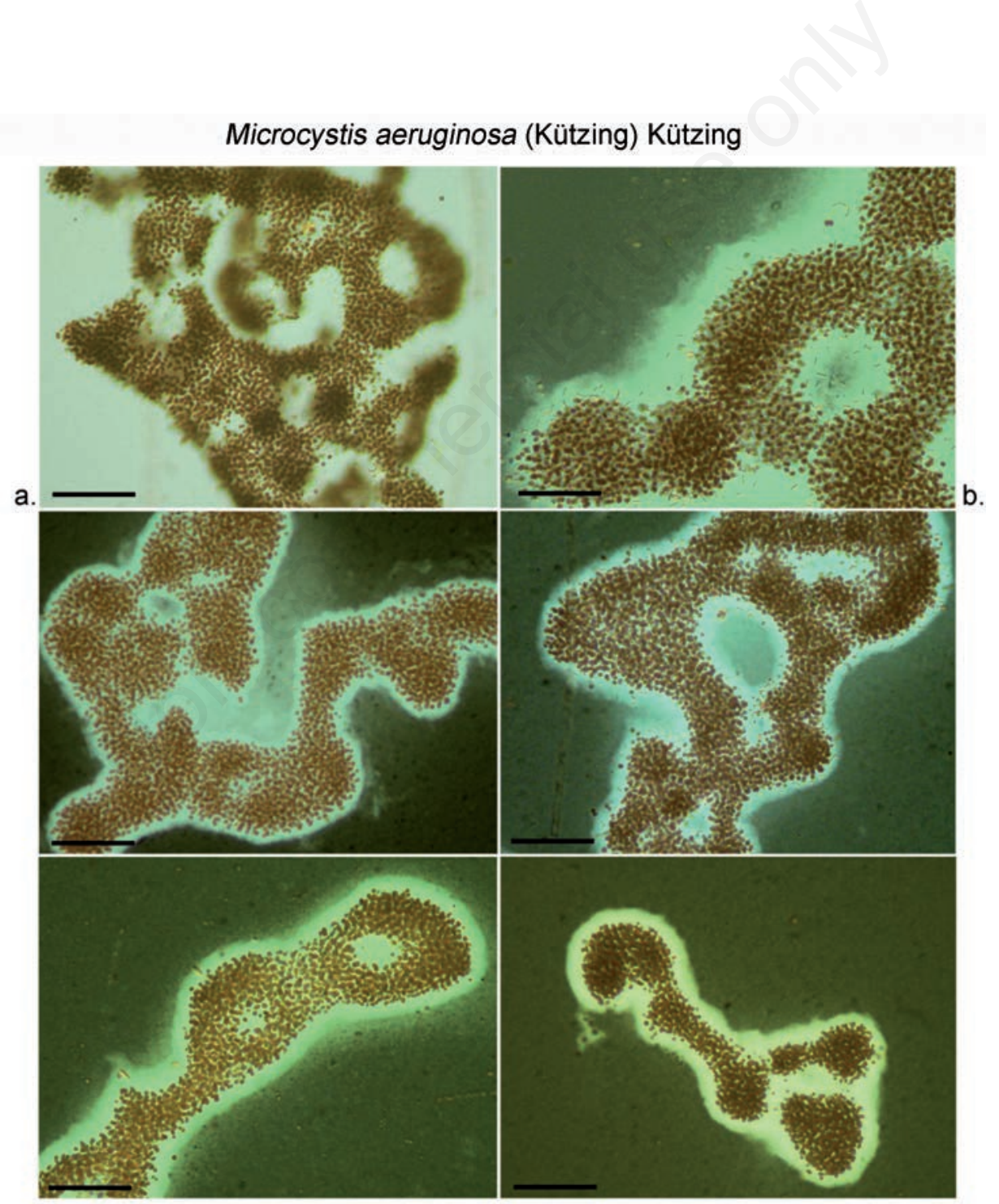

Plate 1. a) Colonies of Microcystis aeruginosa (magnification: $345 x$ ). b) Staining with China ink (magnification: $345 x$ ). Scale bars: $100 \mu \mathrm{m}$. Diacritical characters: cells medium large $(4-7 \mu \mathrm{m})$, green to dark green (sometimes even black because of the huge number of aerotopes), with wide mucilaginous margin around the colony. Colonies up to macroscopic, irregular in outline, lobate and with distinct holes (old colonies). 
wesenbergii was recorded in the pelagic zone, while $M$. smithii was detected only in the littoral zone. It is important to emphasize that all of the nine detected taxa (Plates 1-9) have been recorded in their full development, meaning that all of the morphological criteria were visible and could be clearly and distinctly characterized without transition. These results inevitably lead to a conclusion that all nine detected Microcystis taxa have distinctive features of separate species (Komárková et al., 2005) that have not been transformed over time from another morphospecies. Their ecological preferences might be slightly different since in our study we have not detected the full development of all nine taxa until the overall domination of high eutrophic conditions and temperature during the summer period, which extended towards autumn (Tab. 1). In this context, the ecology of the different species must represent clear and quite important criterion for taxonomic classification (Komárek, 2013).

The taxonomic confusion in the line morphospeciesspecies within the genus Microcystis could have been a result of several problems associated with important biological features of this complex genus. Namely, the full

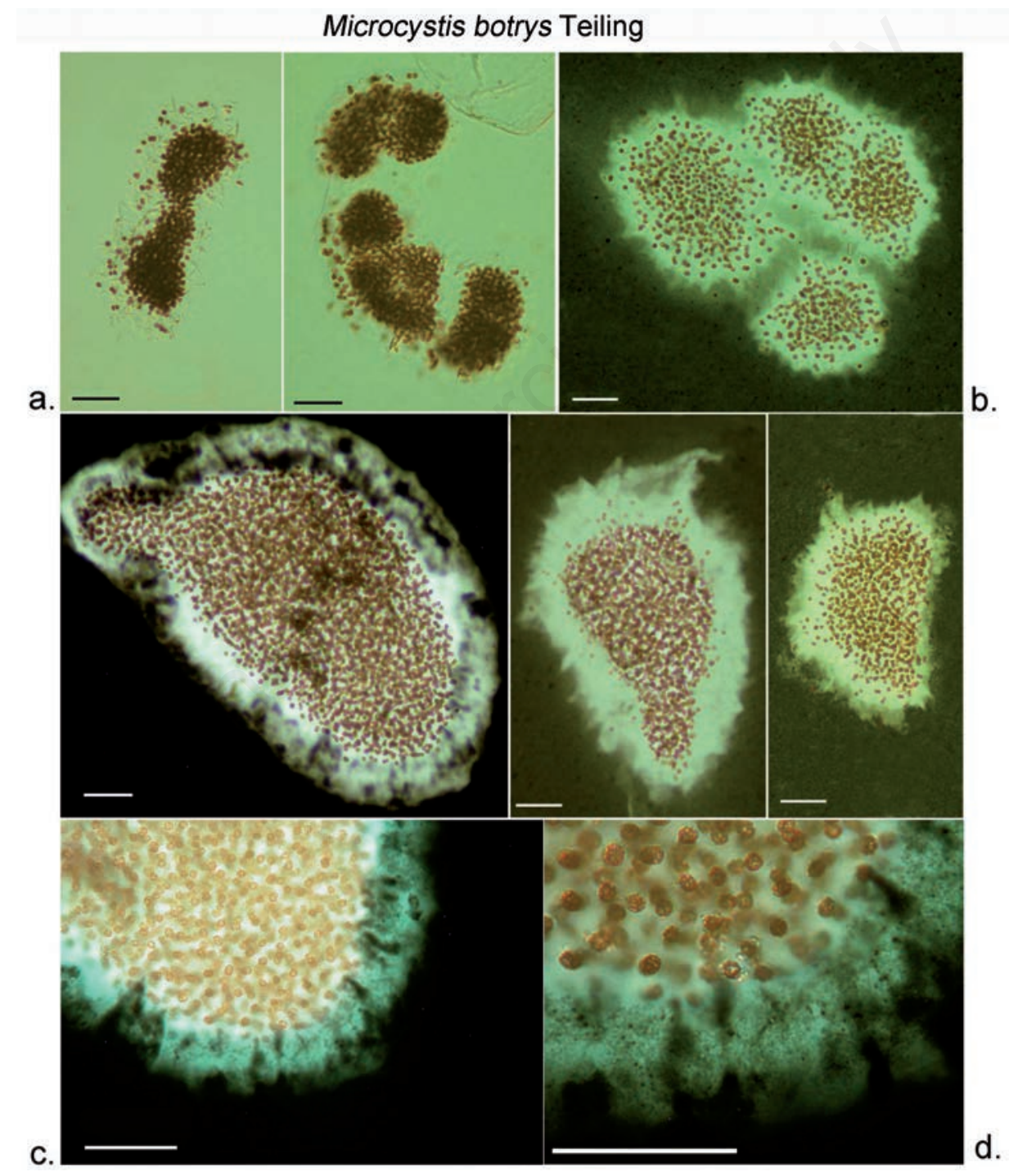

Plate 2. a) Colonies of Microcystis botrys (magnification: 345x). b) Staining with China ink (magnification: $345 x$ ). c) Detail of mucilage (magnification: 690x). d) Detail of mucilage (magnification of magnification: 1380x). Scale bars: $50 \mu \mathrm{m}$. Diacritical characters: cells medium large (4.9-7 $\mu \mathrm{m})$. Colonies microscopic, spheroidal or with composed of spherical sub-colonies, never with holes, usually represented as cluster of quite densely agglomerated cells in the center with few "expulsing" solitary cells in the enveloping mucilage. Mucilaginous margin around the cell clusters quite wide, delimited and with radial semi-globose or tubular structures (staining with China ink is needed!). Diacritical character is the radial structure of the mucilage! 
development of characteristic colonies might be expected after fulfillment of the optimal environmental conditions. The symbiosis with different heterotrophic bacteria seems to be detrimental for a proper development of the protective mucilage that actually determines the colony form (Xie et al., 2016), which on the other hand is essential for the correct taxonomical determination of the species. The vegetation cycle (the stage of development and decomposition of the colonies) in the time of sampling might also have a critical influence on the final taxonomy. On the technical side, it is important always to use China Ink staining in order to properly identify some of the taxa (ex. $M$. botrys is frequently misinterpreted as $M$. aeruginosa - Sant'Anna et al., 2004).

In summary, it seems appropriate to point out the basic morphological and eco-physiological characters that ought to be included in every taxonomical work on this genus. These embrace: i) cell size; ii) pigment content and cell color; iii) mucilage structure, outline and margins; iv) form of the colonies; v) density and organization of the cells in the colony; vi) toxicity and production of bioactive peptides; and vii) ecological preferences; most importantly, it should be stressed that all of these characters usually appear in strict association in the defined types. For example, Microcystis ichthyoblabe (Plate 4) is characterized with small cells (never more than $3.5 \mu \mathrm{m}$ in diameter), usually more or less reddish and the margin of the mucilage never exceeds the margin of the cell clusters in the colony. Contrarily, Microcystis aeruginosa (Plate 1) has always larger cells $(4-7 \mu \mathrm{m})$, which are green to dark green, with wide mucilaginous margin around the colony. In all, we believe that the mutual co-existence of nine $\mathrm{Mi}$ crocystis taxa in the same lake in their fully developed state is an important finding in regard to the controversial opinion by the molecular biologists (Otsuka et al., 2001). This finding, as well as the observed diacritical characters

\section{Microcystis flos-aquae (Wittrock) Kirchner}

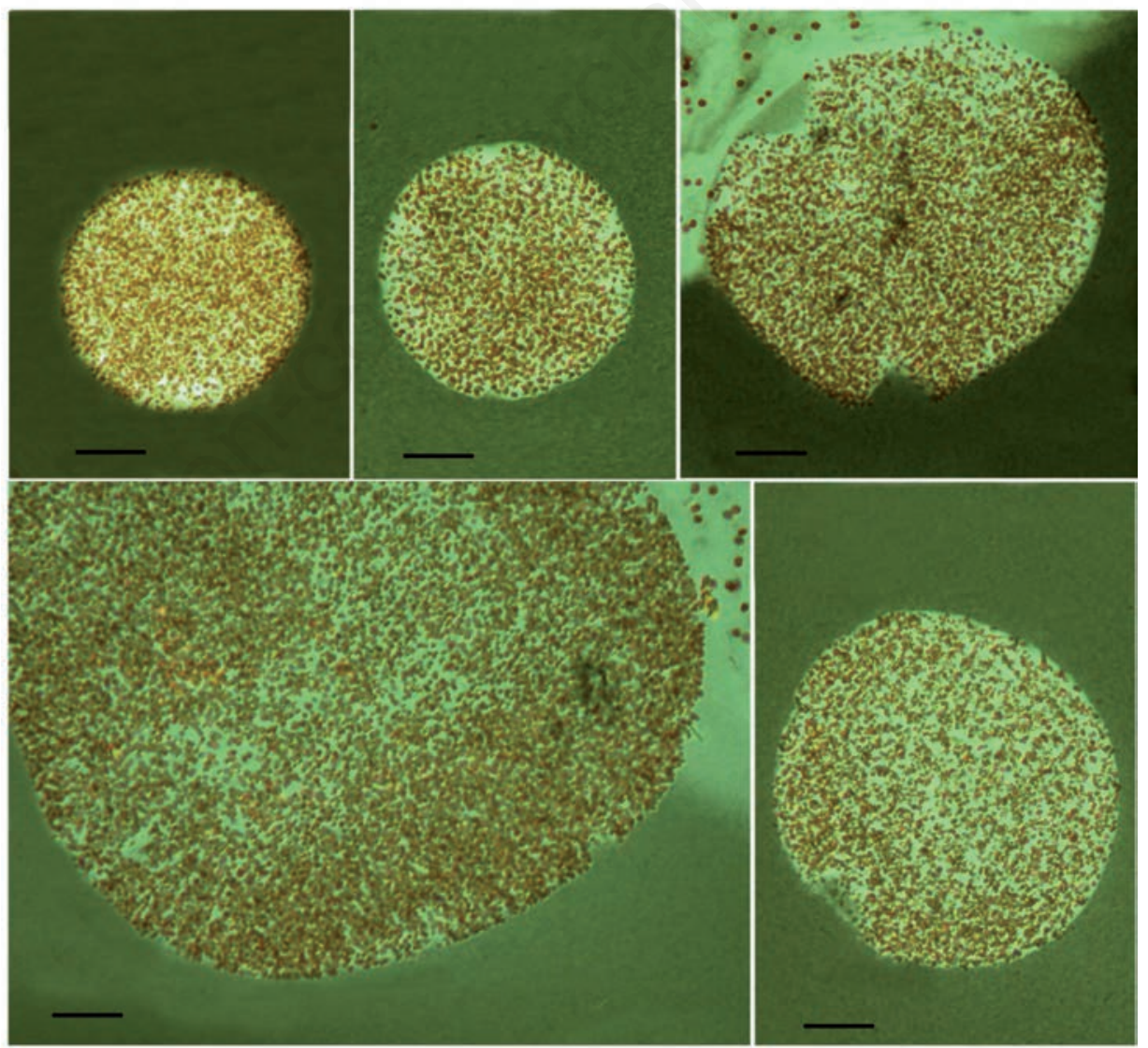

Plate 3. Colonies of Microcystis flos-aquae stained with China ink (total magnification: 345x; scale bars: $50 \mu \mathrm{m}$ ). Diacritical characters: cells small (3.5-4.5 $\mu \mathrm{m}$ in diameter), usually more or less reddish. The margin of the mucilage never exceeds the margin of the cell clusters in the colony! Colonies usually microscopic and regularly spherical (in contrast with M. ichthyoblabe), quite compact, with very densely agglomerated cells. 
that always appear in association in the defined morphotypes, should represent a strong argument against their taxonomic unification.

In the line of previous arguments, we believe that it is important to stress the co-occurrence of nine Microcystis morphospecies/species in one small and shallow lake, like Lake Dojran, which is quite rare according to the literature findings. For example, Šejnohová (2008) in her PhD thesis reports that eight morphospecies have been described in the whole Czech Republic. According to Loudiki et al. (2002), six Microcystis species are present in Morocco. Similarly, six Microcystis species were reported in São
Paulo State, Brazil, after careful and several years' biodiversity studies of planktic cyanobacteria of 14 reservoirs (Sant'Anna et al., 2004). Closest to our results is the report for five Microcystis morphotypes (M. aeruginosa, $M$. flos-aquae, M. ichthyoblabe, M. viridis and M. wesenbergii) in Lake Taihu, China (Hu et al., 2016).

Furthermore, we consider that our results regarding the $M$. protocystis dominance in Lake Dojran deserves a special attention. In our previous paper (Krstic and Aleksovski, 2016), we have reported the presence of $M$. protocystis for the first time in a European lake (Dojran Lake). In the present study, we have performed detailed

a.
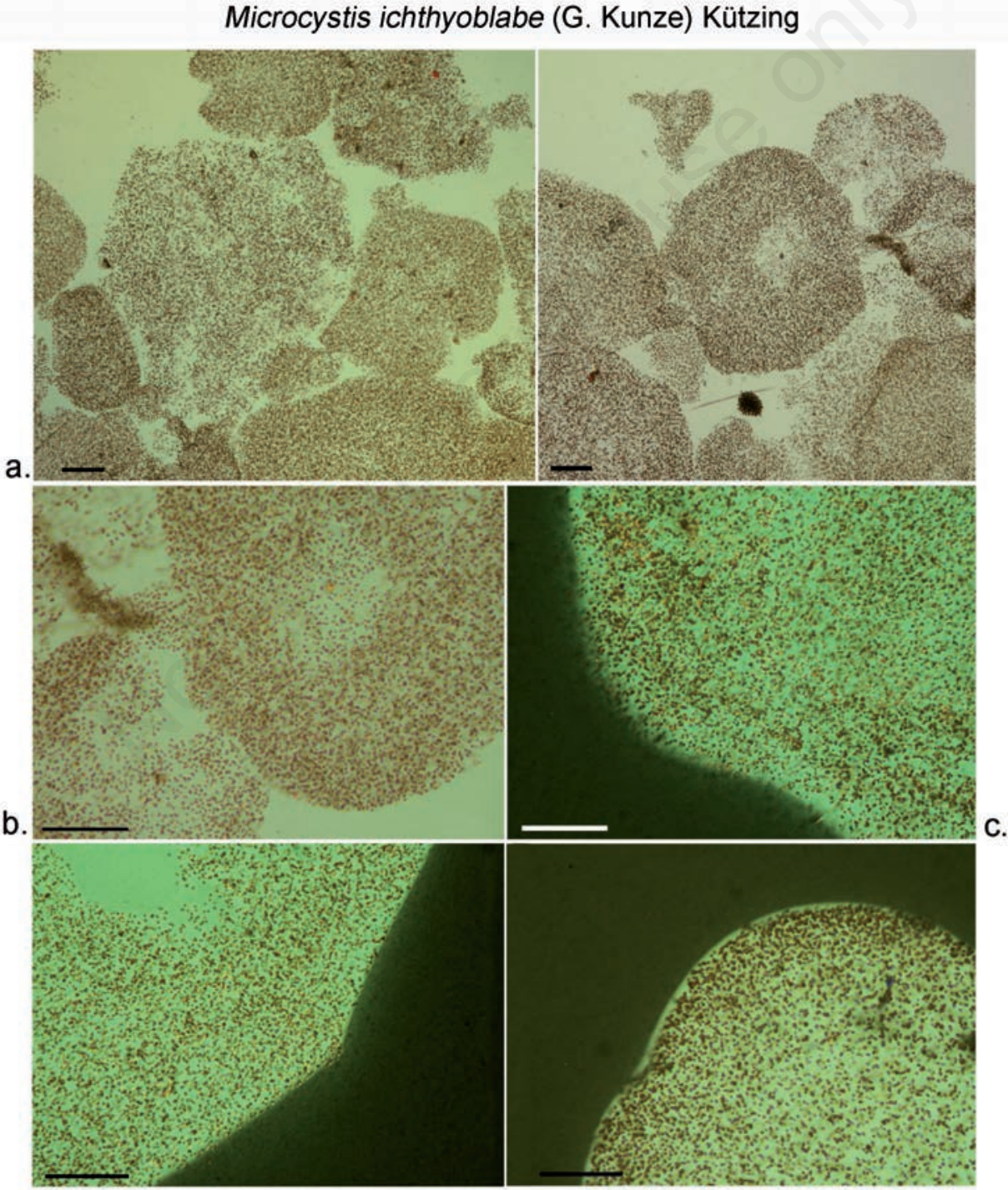

Plate 4. a) Colonies of Microcystis ichthyoblabe (magnification: 138x). b) Colony of Microcystis ichthyoblabe (magnification: 345x). c) Staining with China ink (magnification: $345 \mathrm{x}$ ). Scale bars: $100 \mu \mathrm{m}$. Diacritical characters: cells small (never more than $3.5 \mu \mathrm{m}$ in diameter), usually more or less reddish. The margin of the mucilage never exceeds the margin of the cell clusters in the colony! Colonies up to macroscopic often composed from sub-colonies of cell clusters. 
analyses on the same ecosystem, and the presence of this species was again confirmed with a marked dominance. M. protocystis was originally described by Crow (1923) and the type locality is Sri Lanka, freshwater plankton of the inland waters of Ceylon. Later, this species was characterized as pan-tropical (Komárek \& Anagnostidis, 1999; Komárek \& Komárková, 2002) and probably one of the commonest pan-tropical species. Till now, this species was reported as a true element of plankton in karst environments of the Yucatán peninsula, Mexico (LópezAdrián \& Barrientos-Medina, 2007; Tavera et al., 2013) which are rich in tropical species of cyanobacteria. This species was also reported on several localities in Brazil: in São Paulo State (Sant'Anna et al., 2004), in the Cordeiro, Camalau and Acauã Reservoirs (Vasconcelos et al., 2013) and in Minas Gerais State (Magalhães et al., 2014). It was also found in the neo-tropical, eutrophic reservoir Riogrande II in Colombia (Palacio et al., 2015), but still, up to our knowledge, it was never reported for Europe. However, in one of these papers the authors suggest that the sparse cell disposition gives $M$. protocystis the aspect of old or senescent colonies of different Microcystis species and maybe, for this reason, M. protocystis distribution should be wider than normally referred in the

\section{Microcystis novacekii (Komárek) Compère}

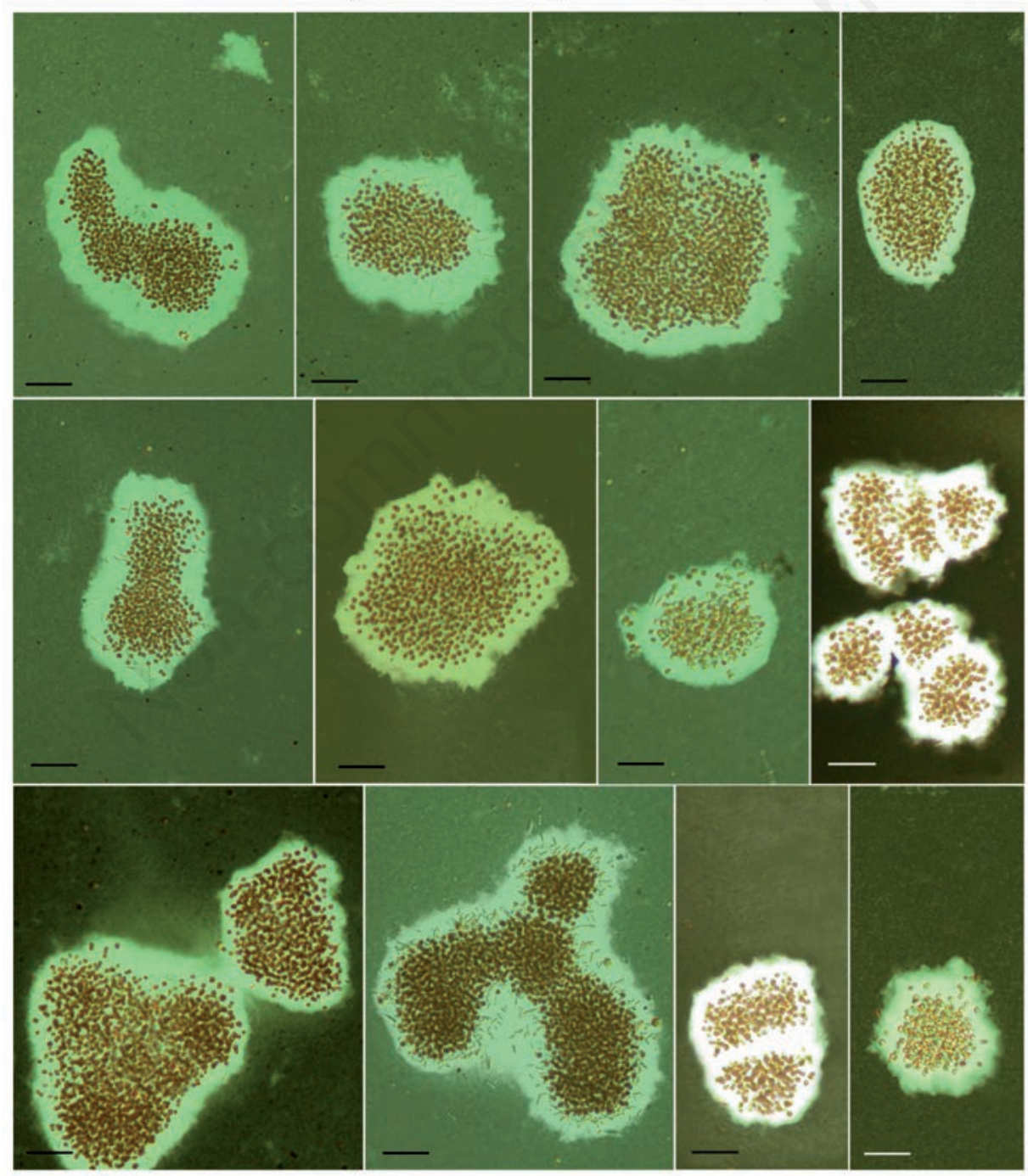

Plate 5. Colonies of Microcystis novacekii stained with China ink (total magnification: $345 x$; scale bars: $50 \mu \mathrm{m})$. Diacritical characters: cells medium large (3-6 $\mu \mathrm{m})$. Colonies microscopic, spheroidal in outline, never with holes, usually represented as cluster of quite densely agglomerated cells in the center with few solitary cells in the enveloping mucilage. Mucilaginous margin around the cell clusters quite wide, delimited and concentrically lamellated (staining with China ink is needed!). 
literature (Sant'Anna et al., 2004). It seems obvious that Dojran Lake is experiencing the accelerated eutrophication processes (Svirčev et al., 2014) due to excessive nutrient input, oxygen depletion and the intensive decomposition on the lake's bottom. Additionally, the evident dominance of this pan/neo-tropical species characteristic for Brazil, Columbia and Sri Lanka in a European lake is an important finding which might have a valuable contribution for the global climate change investigations and may be important for the future monitoring programs.

Last but not least, in the list of arguments on the morphospecies/species subject, the issue of toxicity of the specific taxa becomes both taxonomically and ecologically very important. During our presented investigations, the focus of the research has been pointed to the taxa successions and dominance rather than on the toxicity itself (Tab. 1). The obtained values for this period are quite lower than the values reported in a previous study (Krstić, 2011) when a maximum value of $270 \mu \mathrm{g} \mathrm{L}^{-1}$ has been detected. Detected values for Lake Dojran around 2-5 $\mu \mathrm{g} \mathrm{L}^{-1}$, similar to the findings in our research, have been also reported in some previous studies (Papadimitriou et al., 2010; Gkelis et al., 2015), what underlines the continuity of predominantly microcystin group of toxins presence in the lake. These discrepancies in detected toxin levels for Lake Dojran, or any other ecosystem, would be primarily a result

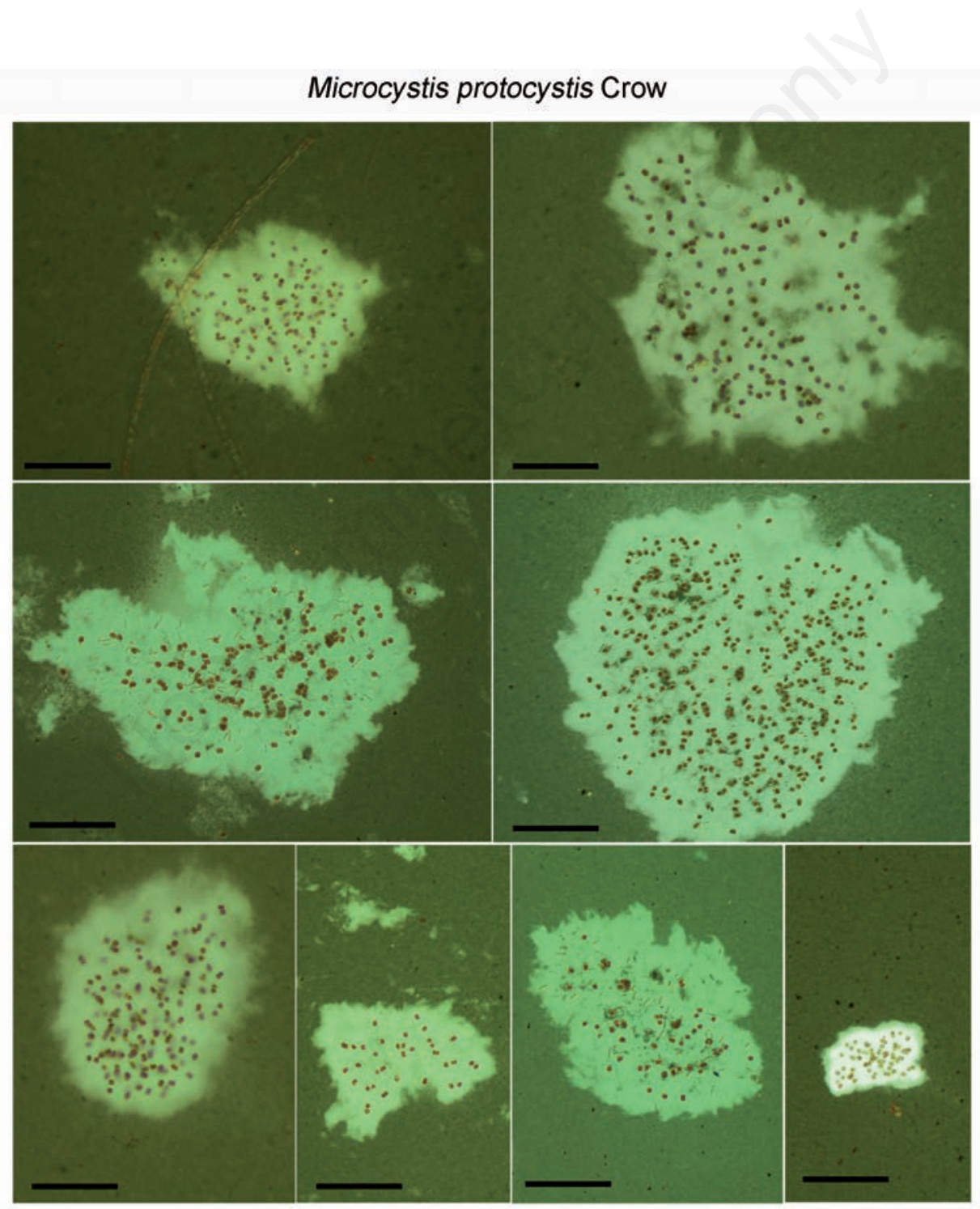

Plate 6. Colonies of Microcystis protocystis stained with China ink (total magnification: $345 x$; scale bars: $100 \mu \mathrm{m})$. Diacritical characters: cells medium large (3.5-6.5 $\mu \mathrm{m})$ and quite loosely situated in the colony (the distances between adjacent cells is always about 2-4 times the cell diameter). Colonies microscopic, irregular (usually with indefinite nature), always without holes and well provided with mucilage. Mucilaginous margin around the colony wide and quite distinct (after staining with China ink!). 
of time of sampling and analyses. As documented in this research, several Microcystis taxa dominance successions have been recorded over the investigated period, meaning that taxa with low/high toxin production potency have changed their dominance and consequently the final toxin (microcystins) concentration in water. Also, some of the dominant taxa like $M$. protocystis, or sub-dominant $M$. ichthyoblabe, have not been hitherto reported to produce any toxins or produce other toxins than microcystins, usually neurotoxins. Thus, the detection of toxins in any ecosystem has to be a specific scientific task which demands a toxin orientated sampling frequency, usually with much denser sampling activities, and also analyses of a broad spectrum of toxins in order to reveal the real toxin dynamics and dominance in an ecosystem. In light of pre- vious findings (Krstic, 2011), it is possible that Dojran Lake undergoes several periods of very high toxin presence (peaks) over the year which may last for couple of days only, and then the ecosystem falls back to the basic microcystins presence of only a few $\mu \mathrm{g} \mathrm{L}^{-1}$. However, the limitations of the ELISA technique should also be considered (mostly used as a screening tool and without possibility to identify the different microcystin variants) as well as our primary focus on extracellular toxins, so future investigations with complementary methods (e.g., LC-MS) are foreseen.

Having in mind the importance of previous arguments, it seems appropriate to list some of the basic toxin properties of dominant taxa detected in Dojran Lake. Also, the toxin potency and genetic ability of different taxa make

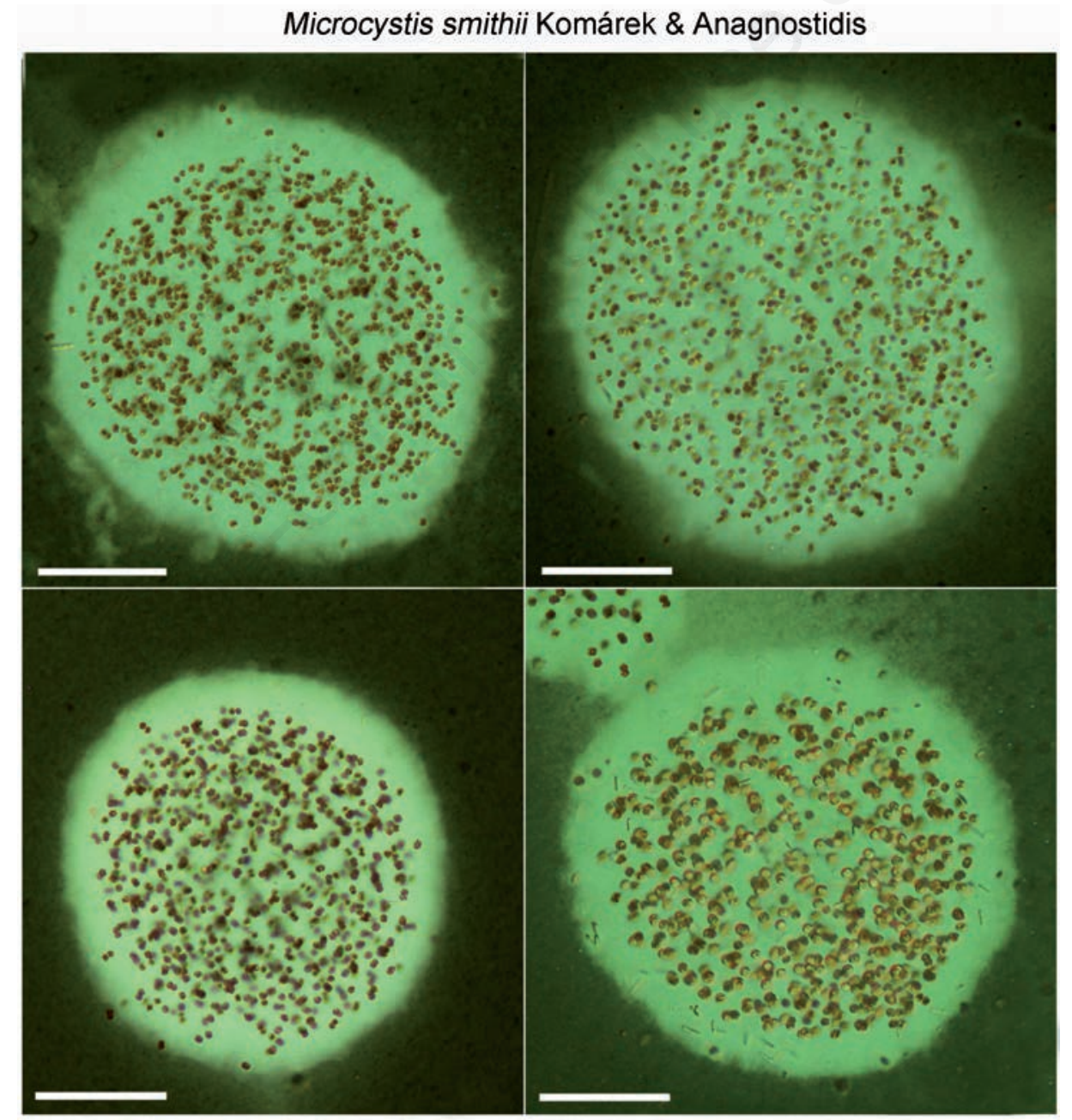

Plate 7. Colonies of Microcystis smithii stained with China ink (total magnification: $345 x$; scale bars: $100 \mu$ m). Diacritical characters: cells medium large $(3.2-5.6 \mu \mathrm{m})$ and quite loosely situated in the colony (the distances between adjacent cells is always larger than the cell diameter). Colonies microscopic, regularly spherical or spheroidal and always without holes. Mucilaginous margin around the colony wide and quite distinct (after staining with China ink!). 


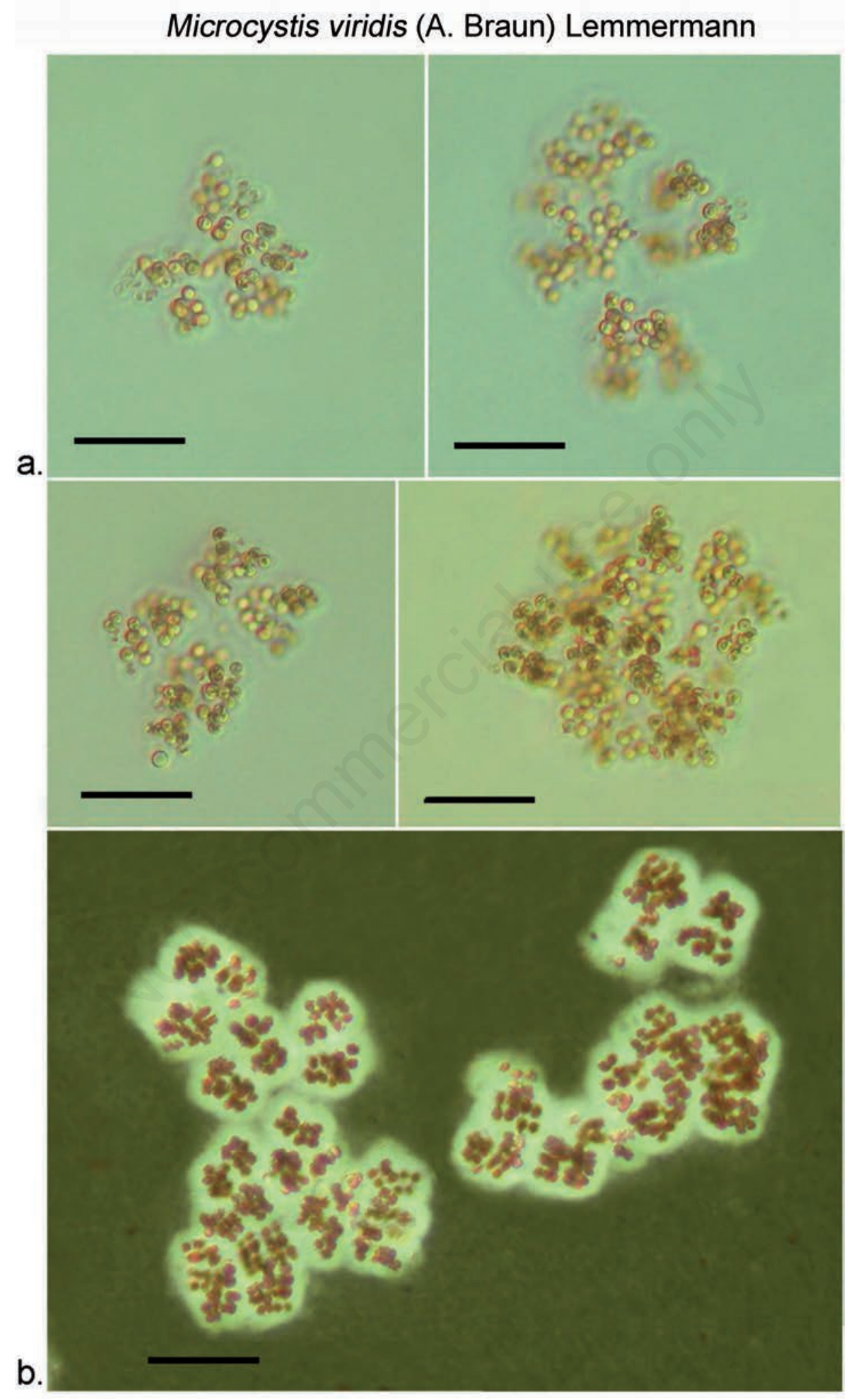

Plate 8. a) Colonies of Microcystis viridis (magnification: $345 \mathrm{x}$ ). b) Staining with China ink (magnification: $345 \mathrm{x}$ ). Scale bars: $50 \mu \mathrm{m}$. Diacritical characters: cells medium large $(4-7.9 \mu \mathrm{m})$ and usually packed tridimensionally (almost cubic). Colonies microscopic composed of packet-like sub-colonies with not very wide mucilage, but with wavy and more or less refractive margin. 
the argument on morphospecies even more obsolete since it is very hard to imagine that a taxon genetically equipped for a toxin production will 'transform' into a taxon not capable of any toxin production, or vice versa. These basic properties are:

- M. aeruginosa: production of neurotoxins and hepatotoxins (Komárek and Anagnostidis, 1998; Komárek and Komárková, 2002), mainly microcystins, occasionally accompanied by aeruginosins (Fastner et al., 2001).

- M. flos-aquae: production of isopropylthio-compounds, without neurotoxins (Komárek and Anagnostidis, 1998; Komárek and Komárková, 2002).

- M. ichthyoblabe: without ability to produce microcystins; presence of anabaenopeptins, microginins, microviridins and unknown peptides (Fastner et al., 2001, Šejnohová, 2008).

- M. novacekii: production of specific aeruginosin and cyanopeptolins, low level of microcystins (Šejnohová, 2008).

- M. viridis: strong toxicity (Komárek \& Komárková, 2002); production of mainly microcystins and cyanopeptolins, presence of microviridins - serine protease inhibitors (Šejnohová, 2008).

- M. wesenbergii: non-microcystin producing (Kurmayer et al., 2002, via-Ordorika et al., 2004); without PCR product of the mcy cluster (Rohrlack et al., 2001, Kurmayer et al., 2002, Via-Ordorika et al., 2004). According to Šejnohová (2008), characterized as non-peptide producing group with large cells and without production of any peptides; however, it is necessary to stress that in contradiction with these results, Fastner et al. (2001) report the production of cyanopeptolins by $M$. wesenbergii.

\section{CONCLUSIONS}

In conclusion, seasonal investigations on Lake Dojran during 2015 on presence, dominance, successions and toxin production of Microcystis spp. have enabled the following statements:

- Lake Dojran has been confirmed as eu-hypereutrophic lake with parameters which are indicative for an increased or accelerated eutrophy over the sampling period spring-autumn;

- A total of nine Microcystis taxa have been observed in co-existence (M. aeruginosa, M. botrys, M. flos-aquae, M. ichthyoblabe, M. novacekii, M. protocystis, M. smithii, $M$. viridis and $M$. wesenbergii), which have successively changed in the dominance over the investi-

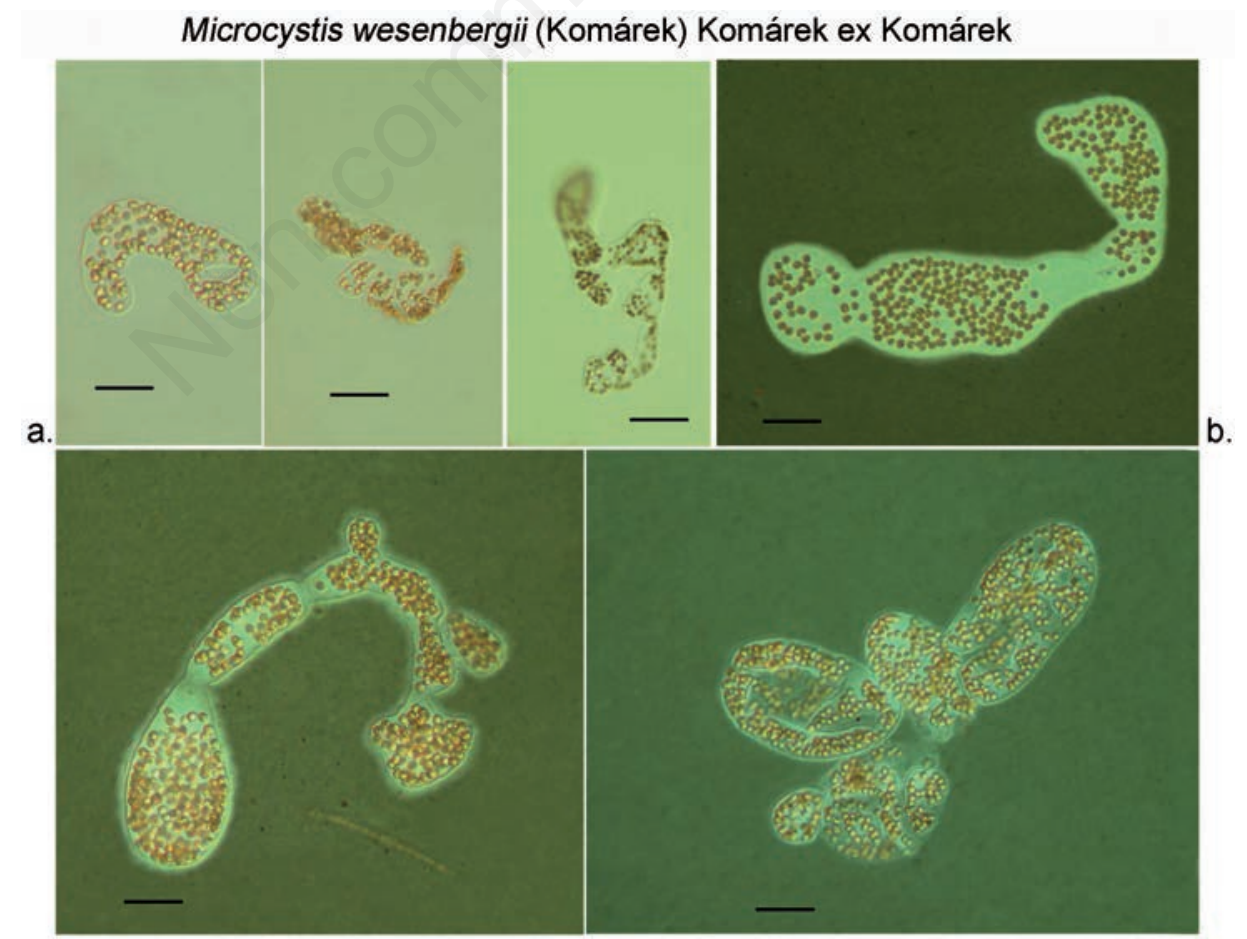

Plate 9. a) Colonies of Microcystis wesenbergii (magnification: 345x). b) Staining with China ink (magnification: 345x). Scale bars: $50 \mu \mathrm{m}$. Diacritical characters: cells large $(6-8.5 \mu \mathrm{m})$. Colonies usually lobate or elongate, with holes when old and often composed of connected spheroidal sub-colonies, with clearly distinct refractive margin of the mucilage. 
gated period. M. protocystis, M. ichthyoblabe and $M$. aeruginosa have been found as the most dominant species in the lake. This is the first report of presence of nine separate Microcystis taxa in a single lake, according to literature data, without transitional forms. We have confirmed the presence of Microcystis protocystis, a pan-tropical species, in a European lake;

- Elaborated results point out the necessity to change the accepted morphospecies concept into separation of Microcystis taxa as distinct species which are clearly delimited according to their constant morphological features. These might be a consequence of genetic constitution or a symbiosis with multiple heterotrophic bacteria. Nevertheless, the co-existence of all nine morphologically different species in a single lake strongly corroborates their distinctive species characters;

- Toxicity analyses demand for a specific and targeted investigation, since the toxin production and presence depends on many factors, and the toxin dynamics including the highest peaks may be easily overlooked if other issues are in the focus of the performed monitoring.

\section{ACKNOWLEDGMENTS}

This work was supported by the REC - local office Skopje in the frame of the project "Developing of capacities for sustainability of Dojran Lake" and also partly by the COST ES 1105 action "CYANOCOST- Cyanobacterial blooms and toxins in water resources: Occurrence, impacts and management". The Authors wish to express their gratitude.

\section{REFERENCES}

APHA, 1998. Standard methods for examination of water and wastewater. 20th ed. American Public Health Association, Washington, DC.

Cronberg G, Komárek J, 1994. Planktic cyanoprokaryotes found in South Swedish lakes during the $12^{\text {th }}$ International Symposium of Cyanophyte research, 1992. Arch. Hydrobiol. 75:323-352.

Crow WB, 1923. The taxonomy and variation of the genus $M i-$ crocystis in Ceylon. New. Phytol. 22:59-68.

Fastner J, Erhard M, Dohren H, 2001. Determination of oligopeptide diversity within a natural population of Microcystis spp. (Cyanobacteria) by typing single colonies by matrix-assisted laser desorption ionization-time of flight mass spectrometry. Appl. Environ. Microbiol. 67:5069-5076.

Franke A, Wagner B, Leng MJ, Rethemayer J, 2013. A late glacial to Holocene record of environmental change from Lake Dojran (Macedonia, Greece). Clim. Past 9:481-498.

Gkelis S, Lanaras T, Sivonen K, 2015. Cyanobacterial toxic and bioactive peptides in freshwater bodies of Greece: concentrations, occurrence patterns, and implications for human health. Mar. Drugs. 13:6319-6335.
Griffiths HI, Reed JM, Leng MJ, Ryan S, Petkovski S, 2002. The recent paleoecology and conservation status of Balkan Lake Dojran. Biol. Cons. 104: 35-49.

Hu L, Shan K, Lin L, Shen W, Huang L, Gan N, Song L, 2016. Multi-year assessment of toxic genotypes and Microcystin concentration in northern Lake Taihu, China. Toxins 8:23.

Komárek J, 2013. Cyanoprokaryota. 3. Heterocytous genera, p. 43-45. In: Büdel, G. Gärtner, L. Krienitz and M. Schagerl (eds.), Süswasserflora von Mitteleuropa/Freshwater flora of Central Europe. Springer Spektrum.

Komárek J, Anagnostidis K, 1998. Cyanoprokaryota 1. Teil: Chroococcales, p. 224-236. In: H. Ettl, G. Gärtner, H. Heynig and D. Mollenhauer (eds.), Süsswasserflora von Mitteleuropa 19/1. Gustav Fischer, Jena.

Komárek J, Komárkova J, 2002. Review of European Microcystis-morphospecies (Cyanoprokaryotes) from nature. Czech Phycol. 2:1-24.

Komárková J, Mugnai M, Sili C, Komárek O, Turrichia S, 2005. Stable morphospecies within the 16S rRNA monophyletic genus Microcystis (Kützing) Kützing. Algol. Stud. 117:279-295.

Krstić S, Stojanovski P, Levkov Z, 1996. Comparative microflora analyses of Anska River, Nikolicka River and Dojran Lake - a possibility for revitalization of lake's microflora. God. Zb. Biol. 49:17-28.

Krstić S, 2011. First records of cyanobacterial blooms, mcy gene cluster presence and cyanotoxins in several freshwater ecosystems in Macedonia. Proc. $16^{\text {th }}$ Scientific Meet. "Cyanobacteria and human health", Academia Studenica, Novi Sad, Serbia.

Krstić S, Aleksovski B, 2016. Dominance of Microcystis spp. in Lake Dojran - a consequence of 30 years of accelerated eutrophication. Bot. Serb. 40:119-128.

Kurmayer R, Dittmann E, Fastner J, Chorus I, 2002. Diversity of microcystin genes within a population of the toxic cyanobacterium Microcystis spp. in Lake Wannsee (Berlin, Germany). Microbial Ecol. 43:107-18.

López-Adrián S, Barrientos-Medina R, 2007. [Diversidad y distribución del fitoplancton de agua dulce en la Península de Yucatán, México].[Article in Spanish]. Ibugana 13:3-13.

Loudiki M, Oudra B, Sabour B, Sbiyyaa B, Vasconcelos V, 2002. Taxonomy and geographic distribution of potential toxic cyanobacterial strains in Morocco. Ann. Limnol.-Int. J. Lim., 38:101-108.

Magalhães S, Brêtas C, Brêtas J, Pianetti G, Franco M, Barbosa F, 2014. Toxic concentrations of metronidazole to Microcystis protocystis. Braz. J. Biol. 74(3 Suppl 1):S120-124.

Otsuka S, Suda S, Shibata S, Oyaizu H, Matsumoto S, Watanabe MM, 2001. A proposal for the unification of fine species of the cyanobacterial genus Microcystis Kutzing ex Lemmermann 1907 under the rules of Bacteriological Code. Int. J. Syst. Evol. Microbiol. 51:873-879.

Palacio H, Ramírez J, Echenique R, Palacio J, Sant'Anna C, 2015. Floristic composition of cyanobacteria in a neo-tropical, eutrophic reservoir. Braz. J. Bot. 38:865-876.

Papadimitriou T, Kagalou I, Bacopoulos V, Leonardos I, 2010. Accumulation of Microcystins in Water and Fish Tissues: An Estimation of Risks Associated with Microcystins in Most of the Greek Lakes. Environ. Toxicol. 25:418-27.

Rohrlack T, Henning M, Kohl J, 2001. Isolation and characterization of colony-forming Microcystis aeruginosa strains, $p$. 
152-158. In: I. Chorus (ed.), Cyanotoxins - occurrence, causes, consequences. Springer Verlag, Heidelberg.

Sant'Anna C, Azevedo M, Senna P, Komárek J, Komárková J, 2004. Planktic Cyanobacteria from São Paulo State, Brazil: Chroococcales. Braz. J. Bot. 27:213-227.

Šejnohová L, 2008. Microcystis. New findings in peptide production, taxonomy and autecology by cyanobacterium Microcystis. PhD Thesis, Czech Academy of Sciences, Průhonice.

Šejnohová L, Maršálek B, 2012. Microcystis, p. 195-228. In: In: B.A. Whitton (ed.), The ecology of Cyanobacteria II. Their diversity in space and time. Springer.

Stojanov P, 1986. Periphyton production of Dojran Lake. Biosistematika 12:87-97.

Stojanov P, Micevski E, 1989. Geology of Lake Doiran and its surrounding. Cont. Mac. Acad. Sci. Arts 10:37-52.

Stojanovski P, Krstić S, Levkov Z, 1996. The phenomenon of microflora dis-balance in Dojran Lake as a direct consequence of the anthropogenic influence. God. Zb. Biol. 49:5-16.

Stojanovski P, Krstić S, Levkov Z, 1997. Changes in Doiran Lake's microflora - a case of rapid turnover towards hypertrophy. God. Zb. Biol. 50:13-24.
Svirčev Z, Krstić S, Važić T, 2014. The philosophy and applicability of ecoremediations for the protection of water ecosystems. Acta. Geog. Slov. 54:179-188.

Tavera R, Novelo E, Lopez S, 2013. Cyanoprokaryota (Cyanobacteria) in karst environments in Yucatan, Mexico. Bot. Sci. 91:27-52.

Vasconcelos J, Barbosa J, Lira W, Azevedo S, 2013. Microcystin bioaccumulation can cause potential mutagenic effects in farm fish. Egyp. J. Aqua. Res. 39: 85-192.

Via-Ordorika L, Fastner J, Kurmayer R, Hisbergues M, Dittmann E, Komárek J, Erhard M, Chorus I, 2004. Distribution of microcystin-producing and non-microcystin-producing Microcystis sp. in European freshwater bodies: detection of microcystins and microcystin genes in individual colonies. Syst. Appl. Microbiol. 27:592-602.

WHO, 1999. Toxic cyanobacteria in water. A guide to their public health consequences, monitoring, and management. World Health Organization, Geneva.

Zacharias I, Bertachas I, Skoulikidis N, Koussouris T, 2002. Greek Lakes: Limnological overview. Lakes Reserv. Res. Manage. 7:55-62. 